\title{
Surfactant Effect as Template Agent on the Morphological and Electrochemical Properties of $\mathrm{V}_{2} \mathrm{O}_{5}$
}

\author{
Fernanda R. Lemos ${ }^{1}$, Leonardo M. da Silva ${ }^{2}$, Dane T. Cestarolli ${ }^{1}$,Elidia M. Guerra, ${ }^{1, *}$ \\ ${ }^{1}$ Department of Chemistry, Biotechnology and Bioprocess Engineering, Federal University of São \\ João Del Rei, Ouro Branco, MG, Brazil \\ ${ }^{2}$ Department of Chemistry, Federal University of Jequitinhonha and Mucuri Valley, Diamantina-MG, \\ Brazil \\ *E-mail: elidiaguerra@ufsj.edu.br
}

doi: $10.20964 / 2016.06 .3$

Received: 19 February 2016 / Accepted: 22 March 2016 / Published: 4 May 2016

\begin{abstract}
The effect of the release of cetylpyridinium chloride surfactant into the $\mathrm{V}_{2} \mathrm{O}_{5}$ following the behavior of lithium intercalation into an electrode containing the $\mathrm{V}_{2} \mathrm{O}_{5}$ film has been investigated. X-ray diffraction patterns indicated formation of a lamellar structure. After the calcination and release of surfactant occurred the formation of an orthorhombic structure. Scanning Electronic Microscopy shows that the route employed for the preparation of an open network $\mathrm{V}_{2} \mathrm{O}_{5}$ structure was successful. The electrochemical performance of the open network structured material compared with a compact structure of $\mathrm{V}_{2} \mathrm{O}_{5}$, via sol-gel route as lithium intercalation cathode materials were evaluated. The open network material reaches stability more easily and presents a high total voltammetric charge after several cycles compared with the $\mathrm{V}_{2} \mathrm{O}_{5}$ xerogel. Lithium intercalation into the $\mathrm{V}_{2} \mathrm{O}_{5}$ electrode is very influenced by open network surface and surface irregularity, in contrast with the compact surface of the $\mathrm{V}_{2} \mathrm{O}_{5}$ xerogel.
\end{abstract}

Keywords: Intercalation reaction; $\mathrm{V}_{2} \mathrm{O}_{5}$ xerogel; open network; surfactant; electrochemical studies

\section{$\underline{\text { FULL TEXT }}$}

(C) 2016 The Authors. Published by ESG (www.electrochemsci.org). This article is an open access article distributed under the terms and conditions of the Creative Commons Attribution license (http://creativecommons.org/licenses/by/4.0/). 